\title{
Type A Spindle Cell Melanoma
}

National Cancer Institute

\section{Source}

National Cancer Institute. Type A Spindle Cell Melanoma. NCI Thesaurus. Code C4238.

A melanoma characterized by the presence of malignant spindle-shaped melanocytes

with slender nuclei and no visible nucleoli. Representative example is the type A spindle cell uveal melanoma. 